\title{
Partial purification, immobilization and preliminary biochemical characterization of lipases from Rhizomucor pusillus
}

\author{
Ana Lúcia Ferrarezi ${ }^{1 *}$, Daniele H. Pivetta ${ }^{2}$, Gustavo Orlando Bonilla-Rodriguez ${ }^{2}$, \\ Roberto da Silva ${ }^{2}$, José Manuel Guisan ${ }^{3}$, Eleni Gomes ${ }^{1}$, Benevides Costa Pessela ${ }^{4}$ \\ ${ }^{1}$ Department of Biology, Laboratory of Applied Biochemistry and Microbiology, IBILCE-UNESP, São José do Rio Preto SP, Brazil; \\ *Corresponding Author: analu fz@hotmail.com \\ ${ }^{2}$ Department of Chemistry and Environmental Sciences, IBILCE-UNESP, São José do Rio Preto SP, Brazil \\ ${ }^{3}$ Department of Enzyme Biocatalysis, Institute of Catalysis and Petrochemistry, CSIC, Campus UAM, Cantoblanco, Madrid, Spain \\ ${ }^{4}$ Department of Biotechnology and Food Microbiology, Research Institute for Food Science, CIAL-CSIC, CalleNicolás Cabrera 9, \\ Campus UAM, Madrid, Spain; ${ }^{*}$ Corresponding Author: b.pessela@,csic.es
}

Received 24 June 2013; revised 14 August 2013; accepted 1 September 2013

Copyright (C) 2013 Ana Lúcia Ferrarezi et al. This is an open access article distributed under the Creative Commons Attribution License, which permits unrestricted use, distribution, and reproduction in any medium, provided the original work is properly cited.

\begin{abstract}
Lipases have important applications in biotechnological processes, motivating us to produce, purify, immobilize and perform a biochemical characterization of the lipase from Rhizomucor pusillus. The fungus was cultivated by solid state fermentation producing lipolytic activity of about $0.5 \mathrm{U} / \mathrm{mL}(4 \mathrm{U} / \mathrm{g})$. A partial purification by gel filtration chromatography in Sephacryl S-100 allowed obtaining a yield of about $85 \%$ and a purification factor of 5.7 . Our results revealed that the purified enzyme is very stable with some significant differences in its properties when compared to crude extract. The crude enzyme extract has an optimum $\mathrm{pH}$ and temperature of $7.5^{\circ} \mathrm{C}$ and $40^{\circ} \mathrm{C}$, respectively. After purification, a shift of the optimum pH from 7 to 8 was observed, as well as a rise in optimumtemperature to $60^{\circ} \mathrm{C}$ and an increase in stability. The enzyme was immobilized on CNBr-Agarose and Octyl-Agarose supports, having the highest immobilization yield of $94 \%$ in the second resin. The major advantage of immobilization in hydrophobic media such as Octyl is in its hyper activation, which in this case was over $200 \%$, a very interesting finding. Another advantage of this type of immobilization is the possibility of using the derivatives in biotechnological applications, such as in oil enriched with omega-3 as the results obtained in this study display the hy-
\end{abstract}

drolysis of $40 \%$ EPA and $7 \%$ DHA from sardine oil, promising results compared to the literature.

Keywords: Enzyme Immobilization; Solid State Fermentation; Purification; n-3 Polyunsatured Fatty Acids; Rhizomucor pusillus

\section{INTRODUCTION}

Lipases are among the most used enzymes in organic chemistry due to their high versatility [1-3], recognizing a broad range of substrates and being used in a very wide range of reactions - from synthesis of structured oils in food technology with fish oil enrichment of polyunsatured fatty acids (PUFAs), to fine chemicals resolution via hydrolytic reactions [4-7]. This diversity of reactions makes lipase derivatives be employed in a wide range of reaction media: from fully aqueous media or water/co-solvent systems to anhydrous systems [1-3,5-8]. This makes the adsorbed lipases be exposed to very different medium conditions, and makes it very interesting to compare different reversible immobilization approaches, useful for each specific application. In this paper, we study different strategies for immobilization by hydrophobic and covalent supports as well as characterization of lipase from Rhizomucor pusillus.

Enzymes, due to their high selectivity, specificity and activity under mild conditions may be a good option as catalyst for a sustainable chemistry $[4,9,10]$. However, they are biological catalysts and their features need to be improved for most industrial applications [11-13]. One 
of these requirements is the convenience of preparing a heterogeneous catalyst, that is, to have the enzyme in an immobilized form [14-16]. Among the existing immobilization strategies, the physical adsorption of the enzyme on suitable supports is a very simple one, just by mixing the enzyme and the support, the enzymes become rapidly immobilized, usually with low impact on the enzyme activity $[17,18]$. This produces a reversible immobilization, and makes reuse of the supports possible after enzyme inactivation, thus, reducing the cost of the production of the biocatalysts $[17,18]$. However, this reversibility may be a problem because the enzyme could desorb from the support during operation, reducing the range of conditions where the immobilized enzymes may be used.

Moreover, based on the particular mechanism of action of lipases, there is one specific immobilization strategy for lipases which is the use of hydrophobic supports. Lipases present two very different structures, changing between a closed form, where the active centre is secluded from the medium by an oligopeptide chain called flap or lid, and an open form where this lid is shifted and the active centre becomes accessible to the substrate [19-21]. When in contact with hydrophobic surfaces, such as oil drops, the open form of lipase is adsorbed, involving the large hydrophobic surface formed by the inner side of the lid and the active centre $[22,23]$. Thus, in the specific case of lipases, one useful immobilization technique is the interfacial activation of the lipase by adsorption of the open form of the enzyme on hydrophobic supports at low ionic strength [19-29].

This simple strategy allows the preparation of hyperactivated lipase preparations, since the open form of the enzyme is stabilized (at least when acting against hydrophobic substrates).

On the other hand, it has been described that the specificity and selectivity of lipases may be greatly altered by the immobilization protocol, due to the conformational changes that the lipases suffer during catalysis $[22,23,28]$ giving, as final result, an immobilized enzyme with very different catalytic properties [14]. Therefore, it is important to evaluate both the activity and stability of the immobilized enzyme before selecting the optimal biocatalyst.

\section{MATERIALS AND METHODS}

\subsection{Preparation of the Fungus by Solid-State Fermentation (SSF)}

$R$. pusillus was preserved on PDA slants. Inoculum was by growing the fungus for 3 days at $45^{\circ} \mathrm{C}$. Solid state fermentation (SSF) was performed in polypropylene bags $(21 \mathrm{~cm} \times 12 \mathrm{~cm})$ containing solid substrate (wheat bran), a spore suspension of $\left(5 \times 10^{5}\right.$ colonies forming units) and standard nutrient solution, containing $20 \mathrm{~g} \cdot \mathrm{L}^{-1}$ peptone, $2 \mathrm{~g} \cdot \mathrm{L}^{-1}$ of $\mathrm{K}_{2} \mathrm{HPO}_{4}$ and $0.5 \mathrm{~g} \cdot \mathrm{L}^{-1}$ of $\mathrm{MgSO}_{4}$. The crude enzyme extract was obtained by addition of 10 $\mathrm{mL}$ of distilled water per gram of fermented material, stirred for $30 \mathrm{~min}$, filtered, and centrifuged at 10,000 g, at $6^{\circ} \mathrm{C}$. Finally, the supernatant was used as a crude enzyme solution for the preliminary biochemical characterization and immobilization.

Samples were withdrawn every 24 hours for 5 days and then their enzymatic activities and protein concentration were determined.

\subsection{Determination of Lipase Activity}

These experiments were carried out by triplicate and the standard error was under $5 \%$.

\subsection{1. $p$-Nitrophenylpalmitate (p-NPP)}

A modified method of [30] was used for soluble and partial pure enzyme. The synthetic substrate used was $p$-nitrophenylpalmitate ( $p$-NPP), and absorbance was read in a Varian Cary 100 spectrophotometer at $410 \mathrm{~nm}$

For the assay was used $0.05 \mathrm{M}$ sodium phosphate buffer ( $\mathrm{pH} 7,0)$, incubation proceeded at $45^{\circ} \mathrm{C}$ for $1 \mathrm{~min}$, and the reaction was stopped with $0.5 \mathrm{~mL}$ of a saturated solution of sodium tetraborate $\left(\mathrm{Na}_{2} \mathrm{~B}_{4} \mathrm{O}_{7}\right)$. The molar extinction coefficient of $\mathrm{p}-\mathrm{NP}\left(\mathrm{e}=3.4 \times 10^{3} \mathrm{~mol} \cdot \mathrm{L}^{-1}\right)$ was used to calculate the initial rate. One unit $(\mathrm{U})$ of enzyme activity was defined as the amount of enzyme that released $1 \mathrm{mmol}$ of $\mathrm{p}$-NP ( $p$-nitrophenol) per minute. For the partially purified enzymes the assays were performed at the optimum conditions: $\mathrm{pH} 8.5$ and $55^{\circ} \mathrm{C}$.

\subsection{2. $p$-Nitrophenyl Butyrate (p-NPB)}

The analysis of the activities of the soluble lipases and their immobilized preparations were performed in a quartz cuvette and analyzed spectrophotometrically by measuring the increase in absorbance at $348 \mathrm{~nm}$ (extincttion molar coefficient $=5150 \mathrm{M}^{-1} \cdot \mathrm{cm}^{-1}$ ) using 0.4 $\mathrm{mMpNPB}$ in $25 \mathrm{mM}$ sodium phosphate buffer at $\mathrm{pH} 7,0$ and $25^{\circ} \mathrm{C}$. Enzyme activity is given as $\mu$ mols of p-NP produced per minute per mg of enzyme (U) under the conditions described earlier.

\subsubsection{Biochemical Characterization of the Crude Extract and Partially Pure Enzyme}

1) Determination of the Optimum $\mathrm{pH}$

The effect of $\mathrm{pH}$ on the enzyme activity was determined at $45^{\circ} \mathrm{C}$ in suitable buffer and $\mathrm{pH}$ ranges of $3-10$ (sodium citrate $0.05 \mathrm{M}$ at $\mathrm{pH} 3$, sodium acetate $0.05 \mathrm{M}$ at pH 4.0 - 5.0, sodium phosphate $0.05 \mathrm{M}$ at $\mathrm{pH} 6.0$ to 8.0 and glycine-NAOH $0.05 \mathrm{M}$ at $\mathrm{pH} 9-10$ ).

2) Determination of $\mathrm{pH}$ Stability

The effect of $\mathrm{pH}$ was tested at $45^{\circ} \mathrm{C}$, checking the enzyme activity every 30 minutes during 4 hours. The 
samples were kept in different buffers from $\mathrm{pH} 6.5$, to 9.5 respectively. The enzyme assays were performed as described earlier.

3) Determination of the Optimum Temperature

The optimum temperature of enzyme activity was determined at temperature ranging from $25^{\circ} \mathrm{C}$ to $70^{\circ} \mathrm{C}$ in sodium phosphate $0.05 \mathrm{M} \mathrm{pH} 7.5$.

4) Determination of Thermal Stability of the Partially Purified Lipases

The thermostability was measured by incubating $4 \mathrm{Ml}$ of enzyme extract at $\mathrm{pH} 8.5$ and $55^{\circ} \mathrm{C}$, the optimum values for the partially purified enzymes. Samples were withdrawn at chosen intervals, cooled and residual activity measured at optimum $\mathrm{pH}$ and temperatures.

\subsection{Determination of Protein Concentration}

Protein concentration was determined as proposed by Bradford [31], using bovine serum albumin as a standard.

\subsection{Gel Filtration Chromatography}

A column $(2.6 \times 100 \mathrm{~cm})$ from Pharmacia filled with Sephacryl S-100 HR was attached to an FPLC (fast performance liquid chromatography) Biologic System (Bio-Rad). The column was equilibrated with $0.05 \mathrm{mM}$ phosphate buffer pH 7.5 containing $0.3 \mathrm{M} \mathrm{NaCl}$. The elution profile was monitored at $280 \mathrm{~nm}$, collecting fractions of $2 \mathrm{ml}$.

\subsection{SDS-PAGE of the Free (Crude or Partial Pure) and the Immobilized Enzyme}

Proteins were analyzed by SDS-PAGE according to Laemmli [32], using a precast $12 \%$ gradient gel (model protean 16; Bio-Rad Laboratories, Richmond, Calif.). Gels were silver-stained. To analyze amount of proteins adsorbed on supports, a sample of the support was first boiled in the presence of $1 \%$ SDS (w/v) and 2\% 2-mercaptoethanol $(\mathrm{v} / \mathrm{v})$ to desorb the proteins. Low molecular weight markers from GE Healthcare were used (14 - 205 $\mathrm{kDa})$.

\subsection{Zymogram Analysis}

The zymogram was used to evaluate the presence of isoenzymes. After the electrophoresis the gel was immersed for 30 minutes in $0.05 \mathrm{M}$ phosphate buffer $\mathrm{pH}$ 7.5 containing $2.5 \%$ Triton X-100 to remove SDS. The gel was subsequently incubated in a mixture of two solutions: Solution A: $1 \mathrm{~mL}$ of acetone was dissolved in 40 $\mathrm{mg}$ of $\alpha$-naphthyl acetate and $30 \mathrm{mg}$ of $\beta$-naphthyl acetate. Solution B: $120 \mathrm{mg}$ of RR-fast-blue was dissolved in $10 \mathrm{~mL}$ of isopropanol. Both solutions were mixed and diluted with $0.1 \mathrm{M}$ phosphate buffer $\mathrm{pH} 6.2$ to $100 \mathrm{~mL}$.
The gel was soaked in the solution mentioned earlier, and incubated at $50^{\circ} \mathrm{C}$ until the bands appeared [33].

\subsection{Stability of the Crude Extract against Different Storage Temperatures}

Samples were kept in different environments: $-80^{\circ} \mathrm{C}$, $-20^{\circ} \mathrm{C}$ and $4^{\circ} \mathrm{C}$ for 30 days. Aliquots of these samples were tested for enzymatic activity at 3 days intervals. The experiments were carried out by triplicate and the standard error was under $5 \%$.

\subsection{Effect of lons on the Lipolytic Activity}

To determine the effects of ions on the enzyme activity $20 \mathrm{~mL}$ of enzyme solution was mixed with different salt solutions: $\mathrm{CaCl}_{2}, \mathrm{MgCl}_{2}, \mathrm{NaCl}, \mathrm{KCl}, \mathrm{MnCl}_{2}$ and $\mathrm{ZnCl}_{2}$ at a final concentration of $2 \mathrm{mM}$. The enzyme activity assays were performed at the optimal conditions of $\mathrm{pH}$ and temperature. The experiments were carried out by triplicate and the standard error was under $5 \%$.

\subsection{Effect of the Fatty Acid Length on the Lipolytic Activity}

The standard substrate used in this study was $p$-nitrophenylpalmitate. However, tests were performed with the following modifications: solution A consisted of each substrate tested: $p$-nitrophenyl stearate, myristate $p$-nitrophenyl, $p$-nitrophenylcaprylate and $p$-nitrophenyl butyrate. Assays were performed in the optimal conditions of activity. The experiments were carried out by triplicate and the standard error was under 5\%.

\subsection{Enzyme Kinetics}

Enzyme assays were performed with different concentrations $(0.1$ to $1.0 \mathrm{mM})$ of $p$-nitrophenylpalmitate, allowing calculating the initial velocity Vo. The kinetic constants $\mathrm{Km}$ and Vmax were calculated by nonlinear regression using the Michaelis-Menten equation $\mathrm{Vo}=$ $(\mathrm{Vmax} .[\mathrm{S}]) /(\mathrm{Km}+[\mathrm{S}])$ as fitting model, using the software QtiPlot version 0.9.8.10 (ProIndepServ SRL, Romania). The experiments were carried out by triplicate and the standard error was under $5 \%$.

\subsection{Immobilization Process of the Isolipases from R. pusilllus}

\subsubsection{Octyl-Agarose Support}

A volume of $10 \mathrm{~mL}$ of enzyme solution $(7 \mathrm{mg}$ total protein/mL determined by Bradford's assay [31]) were mixed with $90 \mathrm{~mL}$ of $10 \mathrm{mM}$ sodium phosphate at $\mathrm{pH}$ 7.0 and $4^{\circ} \mathrm{C}$. Ten grams of octyl-Sepharose previously equilibrated with the immobilization buffer were added. The supernatant and suspension activities were periodi- 
cally checked by the method described previously. After the immobilization, the enzyme derivative was recovered by filtration under vacuum. These adsorbed lipases were used as biocatalyst in the resolution reactions.

To perform other studies, $1.5 \mathrm{mg}$ proteins of enzyme solution were mixed with $1 \mathrm{~g}$ of octyl-Sepharose, in order to prevent diffusion problems. All the other steps were performed as in the standard preparations.

\subsubsection{CNBr-Activated Sepharose Support}

The immobilization of enzyme on CNBr-Sepharose was performed for 15 minutes at $4^{\circ} \mathrm{C}$ to reduce the possibilities of a multipoint covalent attachment between the enzyme and the support. Ten $\mathrm{mL}$ of prepared enzyme solution were added to one gram of support and the reaction was maintained for 40 minutes by constant stirring. Periodically, activity of suspensions and supernatants was measured by $p$-nitrophenyl butyrate as substrate. The enzyme-support immobilization was ended by incubating the support with $1 \mathrm{M}$ ethanolamine at $\mathrm{pH} 8$ for $2 \mathrm{~h}$. Finally, the immobilized preparation was washed several times with $5 \mathrm{mM}$ of sodium phosphate buffer $\mathrm{pH} 7$ [28].

\subsubsection{Immobilization on Glyoxyl-Agarose}

Ten milliliters of enzyme solution were added to 100 $\mathrm{mM}$ sodium bicarbonate buffer at $\mathrm{pH} 10.5$ and the $\mathrm{pH}$ of the final solution was adjusted to $\mathrm{pH} 10.1$. Then one gram of glyoxyl-agarose (aldehyde activated support) was added and the reaction was maintained for $24 \mathrm{~h}$. Periodically, activity of suspensions and supernatants was measured by using the $p$ NPB assay. When the immobilization was finished, $20 \mathrm{mg}$ of $\mathrm{NaBH}_{4}$ were added during $15 \mathrm{~min}$ and then the suspension was filtered and washed abundantly with distilled water $(200 \mathrm{~mL} \times 5)$. The immobilization yield was $>95 \%$.

\subsection{4. pH Stability of the Immobilized Preparations}

Preparations of Octyl and $\mathrm{CNBr}$ activated support was carried out with different buffers. Immobilized preparations were incubated in sodium acetate buffer $10 \mathrm{mM} \mathrm{pH}$ 5; Sodium phosphate buffer $10 \mathrm{mM} \mathrm{pH} 7$ and Sodium bicarbonate buffer $10 \mathrm{mM} \mathrm{pH} 10$. The activity was measured using the pNPB assay.

\subsubsection{Thermal Inactivation of Different Lipase Immobilized Preparations}

The different lipases preparations $(0.5 \mathrm{mg} / \mathrm{g})$ were incubated in $10 \mathrm{mM}$ sodium phosphate at $\mathrm{pH} 7.0$ and $45^{\circ} \mathrm{C}$ $-55^{\circ} \mathrm{C}$. Samples were withdrawn intermittently and their activities were measured using the pNPB assay in the interval 1 - 24 hours. The experiments were carried out by triplicate and error was never over $5 \%$.

\subsection{Analysis of Polyunsaturated Free Fatty Acids (PUFA) by HPLC-UV}

The immobilized lipases were submitted to sardine oil hydrolysis to obtain PUFAs. After a given time, aliquots of $0.1 \mathrm{~mL}$ of organic phase were withdrawn and dissolved in $0.8 \mathrm{~mL}$ of acetonitrile. The organic phase was easily separated (in less than $5 \mathrm{~min}$ ) from the aqueous phase when stirring of the biphasic system was stopped. The unsaturated fatty acids produced were analyzed by RP-HPLC [Spectra Physic SP 100 coupled with an UV detector Spectra Physic SP 8450 (Spectra Physics, Santa Clara, CA. USA)] using a Kromasil C8 $(15 \mathrm{~cm} 90.4 \mathrm{~cm})$ column. Products were eluted at a flow rate of 1.0 $\mathrm{mL} / \mathrm{min}$ using acetonitrile- $10 \mathrm{mMTris}-\mathrm{OH}$ buffer at $\mathrm{pH} 3$ $(70: 30, v / v)$ and UV detection performed at $215 \mathrm{~nm}$. The retention times for the unsaturated fatty acidswere: 9.4 min for EPA and 13.5 min for DHA. These enzymatically produced PUFA were compared to their corresponding pure commercial standards.

\section{RESULTS}

\subsection{Lipase Production}

Maximum enzyme activity was observed at $72 \mathrm{~h}$, as shown in Figure 1, and $0.5 \mathrm{U} / \mathrm{ml}$ equivalent to $4.1 \mathrm{U} / \mathrm{g}$ enzyme activity was obtained during enzyme production.

Maximum lipolytic activity was reached at the third day, decreasing afterwards. This is likely due to the presence of a protease. Another explanation for the dropin enzyme activity could be an inhibitory effect of other metabolites secreted in the course of the fermentation.

\subsection{Partial Purification of Lipases Produced by the Thermophilic Fungus R. pusillus}

The lipases present in the extract were partially purified through gel filtration chromatography (Figure 2), showing at least two enzymes, as deduced from the activity profile. After pooling the fractions with highest activity, we found an $84.9 \%$ yield and a 5.7 purification factor (Table 1). These results can be considered promising when compared to previous works (results not shown). However, when we tried to increase the degree of purification by ion exchange chromatography (DEAE-Sepharose) or hydrophobic interaction (OctylSepharose) the activity decreased significantly. Thus, the characterization experiments were performed using the isolipases partially pure.

When these data are compared to those reported for the lipase from AeromonascaviaeAU04, a mesophilic bacterium by submerged fermentation [34], the authors obtained a total recovery of $28.76 \%$ with a purification factor of 3.4 using phenyl sepharose. After purification by ion exchange chromatography with DEAE-Sepharose, 




Figure 1. Hydrolytic activity of the crude extract obtained bysolid fermentation of the thermophilic fungus Rhizomucor pusillus. The experiments were performed in triplicateand the standard error was under 5\%.

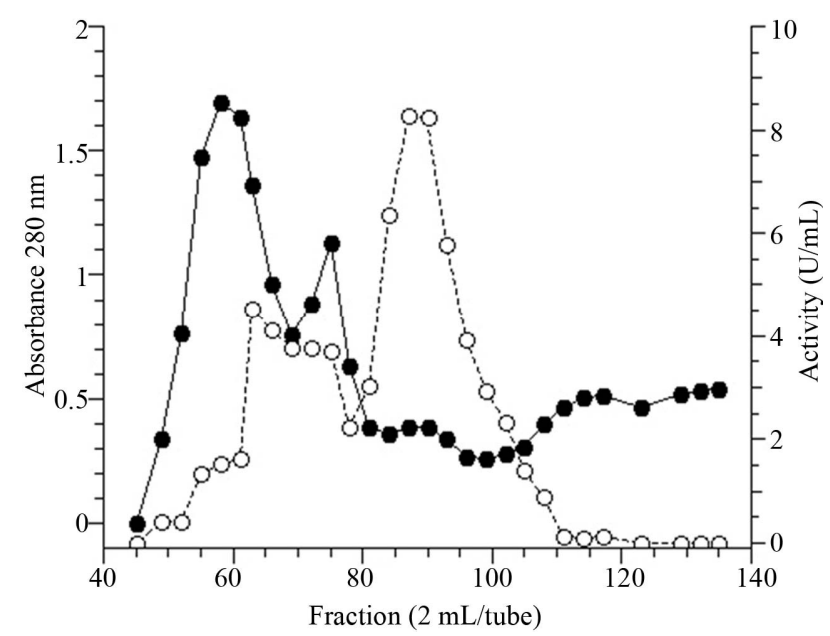

Figure 2. Elution profile of a gel filtration chromatography performed on Sephacryl S-100 support. Conditions: $0.05 \mathrm{M}$ sodium phosphate buffer $\mathrm{pH} 7.5$ containing $0.3 \mathrm{M} \mathrm{NaCl}$. Symbols: (O) protein profile detected at $280 \mathrm{~nm}$; (O) lipolytic activity profile in $\mathrm{U} / \mathrm{mL}$.

Table 1. Partial purification of lipases produced by Rhizomucorpusillus.

\begin{tabular}{ccccccc}
\hline Step & $\begin{array}{c}\text { Volume } \\
\text { (mL) }\end{array}$ & $\begin{array}{c}\text { Total } \\
\text { activity } \\
\text { (U) }\end{array}$ & $\begin{array}{c}\text { Total } \\
\text { protein } \\
\text { (mg) }\end{array}$ & $\begin{array}{c}\text { Specific } \\
\text { activity } \\
\text { (U/mg) }\end{array}$ & $\begin{array}{c}\text { Yield Purification } \\
\text { (\%) }\end{array}$ \\
\hline $\begin{array}{c}\text { Crude } \\
\text { extract }\end{array}$ & 15 & 128.3 & 13.3 & 9.6 & 100.0 & 1.0 \\
$\begin{array}{c}\text { Gel } \\
\text { filtration }\end{array}$ & 13.5 & 108.9 & 2.00 & 55.0 & 84.9 & 5.7 \\
\hline
\end{tabular}

Pastore et al. [35] obtained a $0.4 \%$ yield and purification factor of 3.9 for lipases from Rhizopus $s p$. In the same study, the authors reported $0.4 \%$ of recovery and purifi- cation factor of 6.9 using the hydrophobic resin phenylSepharose.

Liu et al. [36] also purified a microbial lipase; they used gel filtration with Sephadex G-75, obtaining a $12.6 \%$ yield and a purification factor of 3 . After applying to a DEAE-Sepharose column (ion exchange chromatography) obtained $4.8 \%$, of yield and a purification factor of 4.8 fold.

The analysis of the protein profile by SDS-PAGE shows that there are many contaminants remaining after gel filtration (results not shown). This can be caused by the formation of high molecular weight aggregates, commonly reported in studies of purification of lipases, which can hinder the process [37]. The formation of these aggregates may be due to the presence of lipids or the hydrophobic characteristic of the protein structure.

The zymogram profile (results not shown) showed two spots for lipases that would have molecular weights between 44 and $55 \mathrm{kDa}$. The lipase displaying higher molecular weight (the first peak at the gel filtration profile, Figure 2) displayed higher activity.

\subsection{Biochemical Characterization of the Crude Enzymatic Extract and the Partially Purified Lipases}

The lipolytic activity profile as a function of $\mathrm{pH}$ (Figure 3(a)) displayed a peak at $\mathrm{pH} 7.5$ with enzyme activeity. The lipolytic activity of the crude extract was the sameor higher than $70 \%$ in the $\mathrm{pH}$ range from 7 to 10 , whereas for the partially purified extract the highest activity was recorded at $\mathrm{pH} 8.5$, in agreement with optimum $\mathrm{pH}$ values in the literature for lipases, which tend to be alkaline.

This feature is valuable for their potential biotechnological applications, because these lipases could be effective in an alkaline medium, for example in cleaning solutions [38]. It may be noticed that the mixture of these lipases has activity in a wide range of $\mathrm{pH}$ values; between 5 and 9 displays activity above $75 \%$, a feature that suggests a potential application of these enzymes in a range of various reaction conditions.

The difference between the optimum $\mathrm{pH}$ of the enzyme found for the crude extract $(\mathrm{pH} \mathrm{7.5)} \mathrm{and} \mathrm{the} \mathrm{par-}$ tially purified enzymes could be attributed to contaminants that were removed and would interfere in the activity of these enzymes.

The activity profile as a function of temperature (Figure 3(b)) showed that the crude extract had an optimum temperature of $40^{\circ} \mathrm{C}$, and that for the partially pure lipase exhibited a higher value: $55^{\circ} \mathrm{C}$. It is evident that there was an increase in optimum temperature of the partially pure lipase compared to the crude extract. This could be due to the elimination of proteins and proteases that can inhibit the activity of these lipases or denature at lower 



(c)
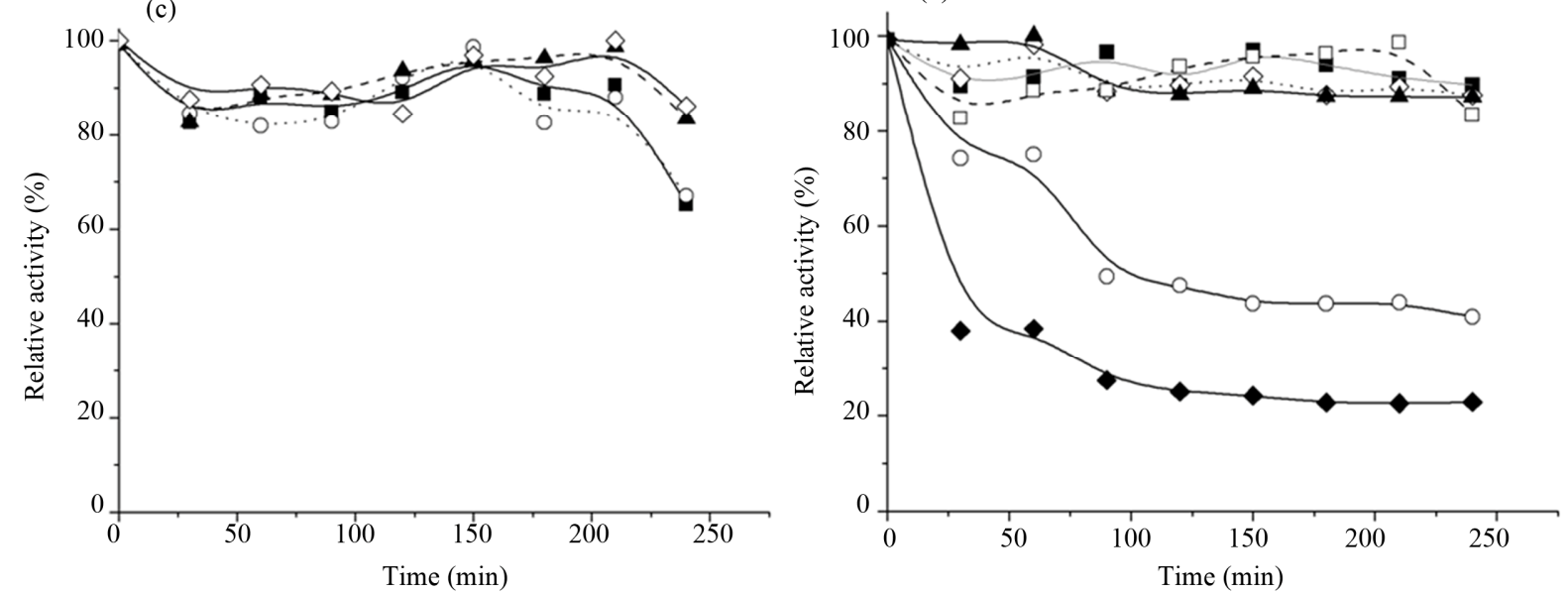

Figure 3. (a) Effect of $\mathrm{pH}$ on the lipolytic activity; (b) Effect of the temperature on the lipolytic activity: Symbols: (ロ) The crude enzymatic extract; ( $\left(\right.$ ) partially purified lipases. (c) $\mathrm{pH}$ Stability of the partially purified lipase maintained at $45^{\circ} \mathrm{C}$ for 4 hours. Conditions: $\mathrm{pH} 8.5$ and $55^{\circ} \mathrm{C}$. Symbols: ( $) \mathrm{pH} 9.5 ;(\circ) \mathrm{pH} 8.5 ;(\boldsymbol{\Delta}) \mathrm{pH} 7.5 ;(\diamond) \mathrm{pH} 6.5$. (d) Thermal stability of the partially pure lipases from $R$. pusillus maintained at different temperatures at $\mathrm{pH} 8.5$ for up to 4 hours. Conditions: $\mathrm{pH}$ 8.5 and $55^{\circ} \mathrm{C}$. Symbols: $(\bullet) 4^{\circ} \mathrm{C} ;(\diamond) 25^{\circ} \mathrm{C} ;(\Delta) 35^{\circ} \mathrm{C}$; (口) $45^{\circ} \mathrm{C}$; (०) $55^{\circ} \mathrm{C} ;(\diamond) 65^{\circ} \mathrm{C}$.

temperatures promoting aggregation with the enzymes.

At temperatures below $40^{\circ} \mathrm{C}$, their activity was low, probably due to the high intrinsic rigidity of thermophilic proteins. These proteins demand high temperature of activity (above $40^{\circ} \mathrm{C}$ ) to promote the thermal motion and increased flexibility essential for catalytic activity [39].

Studies with intracellular lipases from athermophilic Rhizomucor miehei [40], obtained an optimum $\mathrm{pH}$ and temperature of 7.0 and $40^{\circ} \mathrm{C}$ respectively. Another lipase which has similar characteristics produced by a mesophilic Rhizopus oryzae [41] showed optimal conditions of activity at $\mathrm{pH} 7.5$ and $35^{\circ} \mathrm{C}$. Liu et al. [36] also obtained similar results for the lipase from a mesophilic Aureobasidium pullulans HN2.3, which exhibited optimum temperature at $35^{\circ} \mathrm{C}$ and $\mathrm{pH} 8.5$.

Velu et al. [34] studied lipases of Aeromonas caviae and obtained as optimum $\mathrm{pH} 7.0$ and $60^{\circ} \mathrm{C}$. Studying a lipase from a thermophilic Bacillus sp. PTI-001, Nawani, Kaur. [42] found $\mathrm{pH} 8$ and temperature $60^{\circ} \mathrm{C}$ as optimum

\section{conditions.}

Figure 3(c) shows that the lipases partially purified of $R$. pusillus incubated at different $\mathrm{pH}$ were less stable at more alkaline $\mathrm{pH}$ values (8.5 and 9.5) after 150 minutes, with steeper decline than for the samples kept at $\mathrm{pH} 6.5$ and 7.5. Most fungal lipases present maximal activity in a temperature range of $30^{\circ} \mathrm{C}$ to $65^{\circ} \mathrm{C}$. Generally, they have optimal activity at $\mathrm{pH}$ of $(4.5-6.0)$. Furthermore, the enzyme activity is also affected by $\mathrm{pH}$, which affects the enzyme charge distribution and, consequently, the substrate binding and its catalysis.

The thermal stability of these enzymes (Figure 3(d)) is greater when kept at $4^{\circ} \mathrm{C}$, but the enzymatic activity of these lipases remains constant and close to $100 \%$ when kept at temperatures up to $45^{\circ} \mathrm{C}$.

The lipase maintained at $55^{\circ} \mathrm{C}$ showed more than $80 \%$ of its activity within 60 minutes of incubation. After 240 minutes, the enzyme still showed approximately $40 \%$ of its residual activity. 
However, when kept at $65^{\circ} \mathrm{C}$, the lipase activity dropped to $40 \%$ by 60 minutes, which was soon lost, leaving only about $25 \%$ activity at the end of $240 \mathrm{~min}$ utes.

\subsection{Stability of the Lipases from the Crude Extract at Different Storage Conditions}

In order to determine the best storage condition of these crude enzymes, we analyzed the effect of time on enzyme activity for samples stored at different temperatures. When kept frozen at $-80^{\circ} \mathrm{C}$ or $-20^{\circ} \mathrm{C}$, the enzyme displayed a slight loss of activity, but if stored at $4^{\circ} \mathrm{C}$, it lost about more than $30 \%$ of its initial activity after 30 days.

\subsection{Effect of Cations on the Lipolytic Activity}

As is shown in Table 2, most of the tested cations increased activity; the addition of $\mathrm{Mg}^{2+}$ to the enzyme solution, $62.1 \%$ of its activity was increased on the lipase partially purified from Rhizomucor pusillus, which is slightly higher than the activity obtained in the presence of $\mathrm{Na}^{+} \cdot \mathrm{Ca}^{2+}$ and $\mathrm{Mn}^{2+}$ also significantly activated the activity of these lipases, while $\mathrm{K}^{+}$did not practically affect its activity. However, when $\mathrm{Zn}^{2+}$ was added, there was a significant inhibition of enzyme activity.

Sidhu et al. [43] observed that the lipase from Bacillus sp. with optimum temperature of $50^{\circ} \mathrm{C}$ and $\mathrm{pH} 8$ was also activated in the presence of $\mathrm{Ca}^{2+}$ and $\mathrm{Na}^{+}$. Chartrain et al. [44] observed that extracellular lipases of $P$. aeruginosa were activated by $\mathrm{Ca}^{2+}$ (1.26-fold) and strongly inhibited by $\mathrm{Zn}^{2+}$ (94\%). Sharon et al. [45] showed that the activity of lipases from $P$. aeruginosa KKA-5 also increased in the presence of $\mathrm{Ca}^{2+}$ and $\mathrm{Mg}^{2+}$, but were inhibited by $\mathrm{Mn}^{2+}$.

Table 2. Effect of ions ( $2 \mathrm{mM}$ final concentration) in the enzymatic activity of lipases partially purified from $R$. pusillus. Assays were performed in triplicate and analyzed in the optimal conditions of the enzyme ( $\mathrm{pH} 8.5$ and $\left.55^{\circ} \mathrm{C}\right)$.

\begin{tabular}{cc}
\hline Cation & $\begin{array}{c}\text { Relative activity \% (arithmetic } \\
\text { mean } \pm \text { standard deviation) }\end{array}$ \\
\hline CONTROL & $100.0 \pm 0.11$ \\
$\mathbf{C a C l}_{2}$ & $154.6 \pm 0.35$ \\
$\mathbf{M g C l}_{2}$ & $162.1 \pm 0.26$ \\
$\mathbf{N a C l}$ & $159.9 \pm 0.16$ \\
$\mathbf{K C l}$ & $106.2 \pm 0.27$ \\
$\mathbf{Z n C l}$ & $31.9 \pm 0.6$ \\
$\mathbf{M n C l}_{2}$ & $132.8 \pm 0.21$ \\
\hline
\end{tabular}

Many of known enzymes require the presence of metal ions for catalytic activity. These lipases appear to belong to this group (metalloenzymes), behaving as metal-activated enzymes, which they associate weakly to metal ions from solution [46]. In this case, the ions play a structural function, rather than catalytic, since even in the absence of metals, these lipases exhibit high enzyme activity.

\subsection{Effect of the Fatty Acid Chain Length on the Activity of the Partially Purified Lipase}

Tests with different substrates (Table 3) showed that the lipases from Rhizomucor pusillus have more activity with the substrate p-nitrophenylmyristate (C14:0), and decreasing activity with palmitate $(\mathrm{C} 16: 0)>$ caprylate $(\mathrm{C} 8: 0)>$ stearate $(\mathrm{C} 18: 0)$. That is, for the fatty acids tested (all saturated) showed a preference for carbon chains longer than eight carbons, since for p-nitrophenyl butyrate $(\mathrm{C} 4: 0)$ the activity was around $25 \%$ compared with p-nitrophenyl-myristate.

\subsection{Kinetics Parameters of the Enzyme}

From the values of enzyme activity (initial velocity) with different substrate concentrations of p-nytrophenylpalmitate (Figure 4), we estimated the kinetic constants, Vmax and Km (Michaelis-Menten constant). The values obtained by nonlinear regression were $\operatorname{Vmax}=12.6 \pm$ $0.5 \mathrm{mmoles} / \mathrm{min}$ and $\mathrm{Km}=0.2 \pm 0.0 \mathrm{mM}$. It is important to stress that the calculated values for the lipases from $R$. pusillus are apparent, since they are a result of the action of two enzymes.

Comparing these values to other kinetic analyses using the same substrate, Nawani, Kaur [42] analyzed lipases from thermophilic Bacillus sp, finding a $\mathrm{V} \max =0.032$ $\mu$ moles $/ \mathrm{mL}$ and $\mathrm{Km}=0.19 \mathrm{mM}$. Brabcová et al. [47] found a higher $\mathrm{Km}$ for the same substrate for an extracellular lipase from the mesophilic fungus Geotrichum candidum 4013: $0.406 \mathrm{mM}$.

Table 3. Affinity of the partially pure lipase in relation to different synthetic substrates at $0.8 \mathrm{mM}$ final concentration. Assays were performed in optimal conditions of the enzyme for p-NPP (palmitate), $\mathrm{pH} 8.5$ and $55^{\circ} \mathrm{C}$.

\begin{tabular}{cc}
\hline $\begin{array}{c}\text { Substrate } \\
\text { (p-Nitrophenyl-fatty acid) }\end{array}$ & Relative activity (\%) \\
\hline Myristate & $100.0 \pm 0.79$ \\
Palmitate & $91.4 \pm 0.54$ \\
Caprate & $81.5 \pm 0.86$ \\
Stearate & $78.2 \pm 1.34$ \\
Butyrate & $24.7 \pm 1.00$ \\
\hline
\end{tabular}






Figure 4. Enzyme Kinetics performed with different concentrations of p-nitrophenyl-palmitate in the optimal conditions of enzymatic activity: $\mathrm{pH} 8.5$ and $55^{\circ} \mathrm{C}$.

\subsection{Immobilization of Crude Lipases on Octyl-Agarose and CNBr Activated Supports}

Table 4 shows the immobilization course of the crude enzyme octyl-Sepharose and $\mathrm{CnBr}$ supports. In all cases, immobilization was very rapid (full immobilization was achieved after only 15 minutes on octyl-Sepharose).

However, the effect on enzyme activity was very different. Immobilization on the $\mathrm{CNBr}$ did not produce any positive or negative effect on the enzyme activity, while immobilization on octyl-Sepharose increased the enzyme activity by a 10 fold factor. This enhancement in the lipase activity by immobilization on hydrophobic supports hasbeen described previously for many lipases, and it is correlated to its interfacial activation [28,29].

On octyl-Sepharose was achieved almost complete enzyme immobilization and $100 \%$ of the initial enzyme activity was expressed on the support, leaving only $25 \%$ - $30 \%$ of the proteins. In contrast, using the CNBr support only $30 \%$ of activity was immobilized. In fact, the SDS-PAGE analysis of the proteins adsorbed on the supports showed that all proteins have been immobilized in a similar way, while octyl-Sepharose selectively adsorbed about only $50 \%$ of the proteins (Data not shown).

Thus, immobilization on octyl-Sepharose permitted the one step immobilization, purification and hyperactivation of enzymes preparation, while $\mathrm{CNBr}$ is also an efficient method of enzyme immobilization, but neither purify nor hyper activate the lipase.

\subsubsection{Stability of the Immobilized Preparations}

The stability of the derivatives and the soluble enzyme was tested at room temperature and $\mathrm{pH}$ 5. In Figure 5(a), we see that both the soluble enzyme and the derivative
Table 4. Immobilization yield and expressed activity of $R$. pusillus lipase on two different supports.

\begin{tabular}{ccc}
\hline Immobilization supports & $\begin{array}{c}\text { Immobilization } \\
\text { yield (\%) }\end{array}$ & $\begin{array}{c}\text { Expressed } \\
\text { activity (\%) }\end{array}$ \\
\hline CNBr-activated support & 30 & 80 \\
Octyl-agarose support & 95 & 237 \\
\hline
\end{tabular}

prepared on octyl have the same stability profile. Both have some hyperactivation, while $\mathrm{CNBr}$ have a completely different behavior.

The question remains in the behavior of $\mathrm{CNBr}$ derivative, since within the first 5 hours, the activity falls to almost $50 \%$ at $\mathrm{pH} 5$, when the derivative had a higher enzyme expression.

Regarding pH 7 (Figure 5(b)), both the soluble enzyme and derivatives, have a completely different behavior. Here, the two derivatives ( $\mathrm{CNBr}$ and Octyl) have a similar behavior, while the soluble enzyme activity remained almost unchanged, after 24 hours its activity drops by $25 \%$.

At $\mathrm{pH} 10$, the derivative activity in $\mathrm{CNBr}$, drops sharply and the curious case is presented with the soluble enzyme. As they are not completely pure, so that the protein-protein interaction confers some stability and hyperactivation, at some point, unlike the derivative octylagarose, Figure 5(c).

\subsubsection{Thermal Stability of the Immobilized Preparations}

Another interesting feature of an immobilization is the study of the effect of temperature on immobilized enzyme. Figures 6(a) and (b) show the inactivation course of the lipase immobilized on $\mathrm{CnBr}$ and octyl-agarose, stability at $45^{\circ} \mathrm{C}$ and $50^{\circ} \mathrm{C}$ was compared. $\mathrm{CNBr}-$ Sepharose has a mild covalent attachment -having quite similar stability to the soluble enzyme without any intermolecular interactions (e.g., lipase-lipase interactions). Hence, it is intriguing that the $\mathrm{CNBr}$ derivative activity and hyper activity were intact and maintained about $180 \%$ of its initial activity when analyzed at $45^{\circ} \mathrm{C}$.

While the octyl-agarose derivative, which was expected to exhibit this behaviour did not, but rather the hydrophobic and expressed enzyme activity was much higher at the beginning, as shown in Figures 6(a) and (b).

\subsection{Hydrolysis of Sardine Oil Using Immobilized Lipase on Octyl and BrCN-Agarose}

Using octyl-Sepharose derivatives of lipases the hydrolysis of sardine oil under standard reaction conditions was studied, in addition to the HPLC-UV analysis to follow the rate of PUFA release and the EPA/ DHA se- 



Figure 5. (a) Stability of crude extract and immobilized lipase in $\mathrm{pH} 5$; (b) Stability of lipase in the crude extract and immobilized lipase at $\mathrm{pH} 7$; (c) Stability of lipase in the crude extract and immobilized lipase at pH 10. Symbols: Crude extract of soluble lipase; ( $)$ Lipase adsorbed on CNBr-activated; ( $\mathbf{\Delta}$ ) Lipase adsorbed on octyl-agarose.
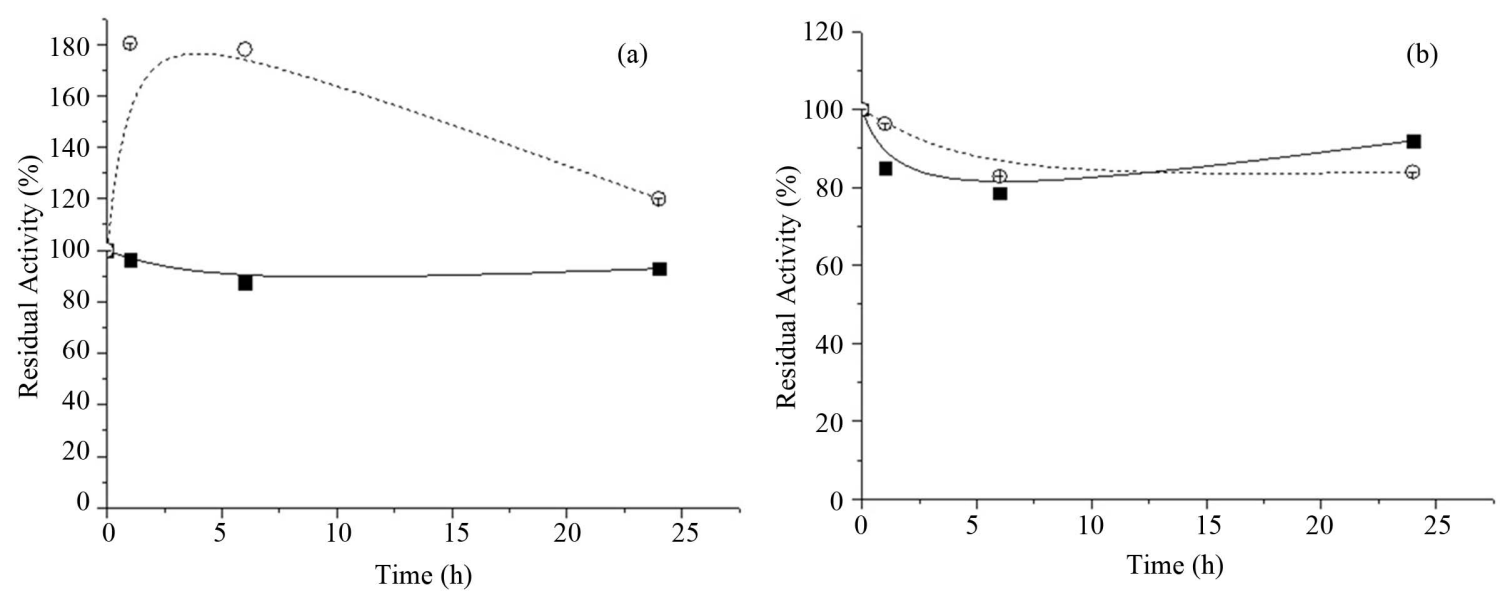

Figure 6. (a)Thermostability of $\mathrm{CNBr}$ derivative at $\mathrm{pH}$ 7. The activity was measured as was described in materials and methods. (b) Thermostability of the Octyl derivative at $\mathrm{pH} 7$; Symbols: (匹) $45^{\circ} \mathrm{C}$; (०) $50^{\circ} \mathrm{C}$.

lectivity. HPLC-light scattering analysis was also carried out to determine lipase selectivity towards polyunsaturated fatty acids:eicosapentaenoic acid (EPA) (20-5, n-3; polyunsaturated fatty acid d) and docosahexanoic acid (DHA) (22-6, n-3; polyunsaturated fatty acid). EPA and DHA are widely available in fishoil and are recognized 
to have beneficial health effects. In this way, the validity of the release of PUFA for the accurate measurement of lipolytic activity of lipases could be determined.

As a routine our group has developed new methodologies for the analysis of both PUFAs(EPA and DHA). Enabling quick analysis of the hydrolysis of these compound with the derivatives, just to see, how they were or not selective in such reactions. Based on this we analyzed only at $\mathrm{pH} 7$ and different temperatures. As shown in Table 5, the octyl derivative achieved the highest yields of EPA and DHA at $37^{\circ} \mathrm{C}$, with selectivity close to 6.

Morrissey and Okada [48] reported the hydrolysis of $33 \%$ of EPA and $29 \%$ of DHA from sardine oil after $9 \mathrm{~h}$ of reaction using the commercial lipase of Candida rugosa (not immobilized) at a concentration of $500 \mathrm{U}$. It is worth mentioning that there is no significant selectivity difference between these two fatty acids, differently from what we observed in this study, with a lipase more selective for EPA. The reaction reported by those authors was faster; however, it took $500 \mathrm{U}$ for hydrolysis, whereas in this work only $130 \mathrm{U}$ were able to carry out the hydrolysis of $40 \%$ and $7 \%$ of EPA and DHA respectively. These promising results have allowed us to work on improving the production of these lipases and search for new and better methods of mobilization for future work.

\section{CONCLUSIONS}

The enzyme was produced with a very good activity level, subsequently with simple purification processes, even without the separation of the isolipases, and yield close to $90 \%$ was obtained.

The expression of the enzyme immobilization mapping is excellent, due to immobilization on octyl-agarose, which reached hyperactivation levels in the order of $200 \%$, which is excellent for studies of enantioselectivity against filing details.

Furthermore, the derivatives stability versus temperature and $\mathrm{pH}$ were excellently allowing use in industry where conditions may be somewhat drastic. The method used of enzyme immobilization applied was very simple

Table 5. Yield of EPA and DHA in 72 hours reaction of hydrolysis of fish oil and selectivity for these fatty acids. Conditions: Fish oil in Tris $10 \mathrm{mM} \mathrm{pH} 7$ buffer and cyclohexaneunder magnetic agitation.

\begin{tabular}{cccc}
\hline Derivative & $\begin{array}{c}\text { EPA } \\
(\mathbf{2 0 : 5} \mathbf{~ n - 3 ) ( \% )}\end{array}$ & $\begin{array}{c}\text { DHA } \\
(\mathbf{2 2 : 6} \mathbf{~ n - 3 ) ( \% )}\end{array}$ & Selectivity \\
\hline Octyl-agarose $\mathrm{pH} 7,25^{\circ} \mathrm{C}$ & 11.2 & 4.2 & 2.7 \\
Octyl-agarose $\mathrm{pH} 7,45^{\circ} \mathrm{C}$ & 10.0 & 2.5 & 4.0 \\
Octyl-agarose $\mathrm{pH} 7,37^{\circ} \mathrm{C}$ & 40.0 & 6.8 & 5.9 \\
\hline
\end{tabular}

and very easy. All amount of the soluble enzyme offered before on each support was completely and quickly adsorbed in all cases with excellent yields on immobilization.

The lipases from R. pusillus showed important characteristics with potential for industrial applications; in particular, they displayed promising results in the enrichment of fish oil with PUFA omega 3.

\section{ACKNOWLEDGEMENTS}

The authors are grateful to Capes-Carolina Foundation (Brazil) for the scholarship of post-doctoral (A.L. Ferrarezi), held at the Instituto de Investigaciones en Ciencias de los alimentos, CIAL-CSIC, Madrid, Spain. The author is thankful to FAPESP and CNPq (Brazil) for financial support and Consolider INGENIO 2010 CSD2007-00063 FUNCFOOD (CICYT), the Spanish Ministry of Science and Innovation.

\section{REFERENCES}

[1] Domínguez De María, P., Carboni-Oerlemans, C., Tuin, B., Bargeman, G., Van Der Meer, A. and Van Gemert, R. (2005) Biotechnological applications of Candida antarctica lipase A: State-of-the-art. Journal of Molecular Catalysis B: Enzymatic, 37, 36-46.

[2] Jaeger, K.E. and Reetz, M.T. (1998) Microbial lipases form versatile tools for biotechnology. Trends in Biotechnology, 16, 396-403.

http://dx.doi.org/10.1016/S0167-7799(98)01195-0

[3] Anderson, E.M., Larsson, K.M. and Kirk, O. (1998) One biocatalyst-Many applications: The use of Candida antarctica B-lipase in organic synthesis. Biocatalysis and Biotransformation, 16, 181-204. http://dx.doi.org/10.3109/10242429809003198

[4] Akoh, C.C., Chang, S.-W., Lee, G.-C. and Shaw, J.-F. (2008) Biocatalysis for the production of industrial products and functional foods from rice and other agricultural produce. Journal of Agricultural Food Chemistry, 56, 10445-10451. http://dx.doi.org/10.1021/jf801928e

[5] Berger, M., Laumen, K. and Schneider, M.P. (1992) Enzymatic esterification of glycerol I. Lipase-catalyzed synthesis of regioisomerically pure 1,3-sn-diacylglycerols. Journal of the American Oil Chemists' Society, 69, 955960.

[6] Chulalaksananukul, W., Condoret, J.-S. and Combes, D. (1993) Geranyl acetate synthesis by lipase-catalyzedtransesterification in supercritical carbon dioxide. Enzyme and Microbial Technology, 15, 691-698. http://dx.doi.org/10.1016/0141-0229(93)90071-9

[7] SzczesnaAntczak, M., Kubiak, A., Antczak, T. and Bielecki, S. (2009) Enzymatic biodiesel synthesis-Key factors affecting efficiency of the process. Renewable Energy, 34, 1185-1194. http://dx.doi.org/10.1016/j.renene.2008.11.013

[8] Holm, H.C. and Cowan, D. (2008) The evolution of enzymatic interesterification in the oils and fats industry. European Journal of Lipid Science and Technology, 110, 
679-691. http://dx.doi.org/10.1002/ejlt.200800100

[9] Brenna, E., Fuganti, C. and Serra, S. (2008) Applications of biocatalysis in fragrance chemistry: The enantiomers of $\alpha-, \beta$-, and $\gamma$-irones. Chemical Society Reviews, 37, 2443-2451. http://dx.doi.org/10.1039/b801557k

[10] Woodley, J.M. (2008) New opportunities for biocatalysis: Making pharmaceutical processes greener. Trends in Biotechnology, 26, 321-327.

http://dx.doi.org/10.1016/j.tibtech.2008.03.004

[11] Iyer, P.V. and Ananthanarayan, L. (2008) Enzyme stability and stabilization-Aqueous and non-aqueous environment. Process Biochemistry, 43, 1019-1032. http://dx.doi.org/10.1016/j.procbio.2008.06.004

[12] Ó’Fágáin, C. (2003) Enzyme stabilization-Recent experimental progress. Enzyme and Microbial Technology, 33, 137-149.

[13] Shaw, A. and Bott, R. (1996) Engineering enzymes for stability. Current Opinion in Structural Biology, 6, 546550. http://dx.doi.org/10.1016/S0959-440X(96)80122-9

[14] Mateo, C., Palomo, J.M., Fernandez-Lorente, G., Guisan, J.M. and Fernandez-Lafuente, R. (2007) Improvement of enzyme activity, stability and selectivity via immobilization techniques. Enzyme and Microbial Technology, 40, 1451-1463. http://dx.doi.org/10.1016/j.enzmictec.2007.01.018

[15] Illanes, A. (1999) Stability of biocatalysts. Electronic Journal of Biotechnology, 2, 15-30. http://dx.doi.org/10.2225/vol2-issue1-fulltext-2

[16] Gianfreda, L. and Scarfi, M.R. (1991) Enzyme stabilization: State of the art. Molecular and Cellular Biochemistry, 100, 97-128. http://dx.doi.org/10.1007/BF00234161

[17] Katchalski-Katzir, E. (1993) Immobilized enzymesLearning from past successes and failures. Trends in Biotechnology, 11, 471-478. http://dx.doi.org/10.1016/0167-7799(93)90080-S

[18] Hartmeier, W. (1985) Immobilized biocatalysts-From simple to complex systems. Trends in Biotechnology, 3, 149-153. http://dx.doi.org/10.1016/0167-7799(85)90104-0

[19] Brady, L., Brzozowski, A.M., Derewenda, Z.S., Dodson, E., Dodson, G., Tolley, S., Turkenburg, J.P., Christiansen, L., Huge-Jensen, B., Norskov, L., Thim, L. and Menge, U. (1990) A serine protease triad forms the catalytic centre of a triacylglycerol lipase. Nature, 343, 767-770. http://dx.doi.org/10.1038/343767a0

[20] Brzozowski, A.M., Derewenda, U., Derewenda, Z.S., Dodson, G.G., Lawson, D.M., Turkenburg, J.P., Bjorkling, F., Huge-Jensen, B., Patkar, S.A. and Thim, L. (1991) A model for interfacial activation in lipases from the structure of a fungal lipase-inhibitor complex. Nature, 351, 491-494. http://dx.doi.org/10.1038/351491a0

[21] Derewenda, Z.S., Derewenda, U. and Dodson, G.G. (1992) The crystal and molecular structure of the Rhizomucor miehei triacylglyceride lipase at $1.9 \AA$ resolution. Journal of Molecular Biology, 227, 818-839. http://dx.doi.org/10.1016/0022-2836(92)90225-9

[22] Schmid, R.D. and Verger, R. (1998) Lipases: Interfacial enzymes with attractive applications. Angewandte Che- mie International Edition, 37, 1609-1633. http://dx.doi.org/10.1002/(SICI)1521-3773(19980703)37: 12<1608::AID-ANIE1608>3.0.CO;2-V

[23] Verger, R. (1997) "Interfacial activation" of lipases: Facts and artifacts. Trends in Biotechnology, 15, 32-38. http://dx.doi.org/10.1016/S0167-7799(96)10064-0

[24] Pessela, B.C.C., Munilla, R., Betancor, L., Fuentes, M., Carrascosa, A.V., Vian, A., Fernandez-Lafuente, R. and Guisán, J.M. (2004) Ion exchange using poorly activated supports, an easy way for purification of large proteins. Journal of Chromatgraphy A, 1034, 155-159.

[25] Fuentes, M., Mateo, C., Pessela, B.C.C., Batalla, P., Fernandez-Lafuente, R. and Guisán, J.M. (2007) Solid phase proteomics: Dramatic reinforcement of very weak protein-protein interactions. Journal of Chromatography B, 849, 243-250.

[26] Kumar, A., Galaev, I.Yu. and Mattiasson, B. (2000) Polymer displacement/shielding in protein chromatography. Journal of Chromatography B, 74, 103-113. http://dx.doi.org/10.1016/S0378-4347(00)00089-X

[27] Mateo, C., Abian, O., Fernandez-Lafuente, R. and Guisan, J.M. (2000) Reversible enzyme immobilization via a very strong and nondistorting ionic adsorption on support-polyethylenimine composites. Biotechnology and Bioengineering, 68, 98-105.

http://dx.doi.org/10.1002/(SICI)1097-0290(20000405)68: $1<98:$ :AID-BIT12>3.0.CO;2-T

[28] Bastida, A., Sabuquillo, P., Armisen, P., Fernández-Lafuente, R., Huguet, J. and Guisán, J.M. (1998) A single step purification, immobilization, and hyperactivation of lipases via interfacial adsorption on strongly hydrophobic supports. Biotechnology and Bioengineering, 58, 486493.

[29] Fernandez-Lafuente, R., Armisén, P., Sabuquillo, P., Fernández-Lorente, G. and Guisán, J.M. (1998) Immobilization of lipases by selective adsorption on hydrophobic supports. Chemistry and Physics of Lipids, 93, 185-197.

[30] Winkler, U.K. and Stuckmann, M. (1979) Glycogen, hyaluronate and some other polysaccharides greatly enhance the formation of exolipase by Serratia marcescens. Journal of Bacteriology, 138, 663-670.

[31] Bradford, M.M. (1976) A rapid and sensitive method for the quantitation of microgram quantities of protein utilizing the principle of protein-dye bindind. Analitical Biochemistry, 72, 248-254.

http://dx.doi.org/10.1016/0003-2697(76)90527-3

[32] Laemmli U.K. (1970) Cleavage of structural proteins during the assembly of the head of bacteriophage T4. Nature, 277, 680-685.

http://dx.doi.org/10.1038/227680a0

[33] Fuciños, P., Abadin, C.M., Sanroman, A., Longo, M.A., Pastrana, L. and Rúa, M.L. (2005) Identification of extracellular lipases/esterases produced by Thermus thermophilus B27: Partial purification and preliminary biochemical characterization. Journal of Biotechnology, 117, 233-241. http://dx.doi.org/10.1016/j.jbiotec.2005.01.019

[34] Velu, N., Divakar, K., Nandhinidevi, G. and Gauntam, P. (2012) Lipases from Aeromonas caviae AU04: Isolation, purification and protein aggregation. Biocatalysis and 
Agricultural Biotechnology, 1, 45-50. http://dx.doi.org/10.1016/j.bcab.2011.08.004

[35] Pastore, G.M., Costa, V.S.R. and Koblitz, M.G.B. (2003) Production, partial purification and biochemical characterization of a novell Rhizopus sp. strain lipase. Ciência e Tecnologia de Alimentos, 23, 135-140. http://dx.doi.org/10.1590/S0101-20612003000200006

[36] Liu, Z., Chi, Z., Wang, L. and Li, J. (2008) Production, purification and characterization of an extracellular lipase from Aureobasidium pullulans HN2.3 with potential application for the hydrolysis of edible oils. Biochemical Engineering Journal, 40, 445-451. http://dx.doi.org/10.1016/j.bej.2008.01.014

[37] Lima, V. M.G., Krieger, N., Mitchell, D.A., Baratti, J.C., Filippis, I. and Fontana, J.D. (2004) Evaluation of the potential for use in biocatalysis of a lipase from a wild strain of Bacillus megaterium. Journal of Molecular Catalysis B: Enzymatic, 31, 53-61. http://dx.doi.org/10.1016/j.molcatb.2004.07.005

[38] Sharma, R., Chisti, Y. and Banerjee, U.C. (2001) Production, purification, characterization, and applications of lipases. Biotechnology Advances, 9, 627-662. http://dx.doi.org/10.1016/S0734-9750(01)00086-6

[39] Gomes, E., Guez, M.A.U., Martin, N. and Silva, R. (2007) Thermostable enzymes: Sources, production and industrial applications. Química Nova, 30, 136-145. http://dx.doi.org/10.1590/S0100-40422007000100025

[40] Adamczak, M. and Bednarski, W. (2004) Enhanced activity of intracellular lipases from Rhizomucor miehei and Yarrowia lipolytica by immobilization on biomass support particles. Process Biochemistry, 39, 1347-1361. http://dx.doi.org/10.1016/S0032-9592(03)00266-8

[41] Hiol, A., Jonzo, M.D., Rugani, N., Druet, D., Sarda, L. and Comeau, L.C. (2000) Purification and characterization of an extracellular lipase from thermophilic Rhizopus oryzae strain isolated from palm fruit. Enzyme and Microbial Technology, 26, 421-430.
http://dx.doi.org/10.1016/S0141-0229(99)00173-8

[42] Nawani, N. and Kaur, J. (2007) Studies on lipolytic isoenzymes from a thermophilic Bacillus sp: Production, purification and biochemical characterization. Enzyme and Microbial Technology, 40, 881-887. http://dx.doi.org/10.1016/j.enzmictec.2006.07.006

[43] Sidhu, P., Sharma, R., Soni, S.K. and Gupta, J.K. (1998) Production of extracellular alkaline lipase by a new thermophilic Bacillus sp. Folia Microbiologica, 43, 51-54. http://dx.doi.org/10.1007/BF02815542

[44] Chartrain, M., Katz, L., Marcin, C., Thien, M., Smith, S., Fisher, E., Goklen, K., Salmon, P., Brix, T., Price, K. and Greasham, R. (1993) Purification and characterization of a novel bioconverting lipase from Pseudomonas aeruginosa MB 5001. Enzyme and Microbial Technology, 15, 575-580. http://dx.doi.org/10.1016/0141-0229(93)90019-X

[45] Sharon, C., Furugoh, S., Yamakido, T., Ogawa, H.I. and Kato, Y. (1998) Purification and characterization of a lipase from Pseudomonas aeruginosa KKA-5 and its role in castor oil hydrolysis. Journal of Industrial Microbiology and Biotechnology, 20, 304-307. http://dx.doi.org/10.1038/sj.jim.2900528

[46] Ali, M.S., Yun, C.C., Chor, A.L., Rahman, R.N., Basri, M. and Salleh, A.B. (2012) Purification and characterisation of an F16L mutant of termostable lipase. The Protein Journal, 31, 229-237. http://dx.doi.org/10.1007/s10930-012-9395-8

[47] Bradcova, J., Zarevucka, M. and Mackova, M. (2010) Diferences in hydrolytic abilities of two crude lipases from Geotrichum candidum 4013. Yeast, 27, 1029-1038. http://dx.doi.org/10.1002/yea.1812

[48] Okada, T. and Morrissey, M.T. (2011) Production of n-3 polyunsatured fatty acid concentrate from sardine oil by lipase catalyzed hydrolysis. Food Chemistry, 103, 14111419. http://dx.doi.org/10.1016/j.foodchem.2006.10.057 